\title{
PSYCHOLOGY AS A NATURAL SCIENCE IN THE EIGHTEENTH CENTURY
}

\author{
Gary HATFIELD
}

\begin{abstract}
Résume : La psychologie, en tant que science naturelle, prend sa source dans la "physique "ou "philosophie naturelle * aristotélicienne de l'âme. C. Wolff a situé la psychologie sous le régime de la métaphysique; au même niveau que la cosmologie. Les penseurs écossais l'ont intégrée d̀ la philosophie morale, mais ont distingué ses lois "physiques * des lois morales proprement dites (qui visent à régler la conduite). Plusieurs penseurs allemands ont cherché à la fonder comme branche autonome de la science naturelle empirique. En Grande-Bretagne et en France, les théoriciens de la vision ont développé des théories de la perception de la grandeur et de la distance d'une grande précision mathématique; quelques-uns d'entre eux ont construit des instruments pour mettre à l'éprewe ces théories et mesurer des phénomènes tels que la durée des impressions visuelles. Ces investigateurs étaient pour la plupart des dualistes qui incluaient les phénomènes mentaux dans la nature.
\end{abstract}

Let us agree that "psychology" may be defined as the science of the mind, and that this science studies a domain of phenomena that includes sense perception, imagination, memory, understanding or reasoning, feeling, and will ${ }^{1}$. If we then interpret the term "natural science" as it was understood in the early modern period, psychology considered as a natural science already had a long history as the eighteenth century began. The prescribed domain of subject-matter was investigated by Aristotle under the name "logon peri tes psyches", of which it formed a proper part. This Aristotelian discipline was widely studied and taught in the early modern period under the title "de anima", or, with increasing frequency, "psycho-

1. "Psychology" was so defined in major textbooks into the 1920s : George Trumbull LadD, Psychology, Descriptive and Explanatory, New York, Scribner's Sons, 1895, p. 1-2; William James, Psychology (Briefer Course), New York, Holt \& Co., 1892, p. 1; Harvey A. CARR, Psychology: A Study of Mental Activity, New York/London, Longmans, Green \& Co., 1925, p. 1. Also, Théodule Rubot, La Psychologie anglaise contemporaine, 3rd éd., Paris, F. Alcan, 1896, p. 42.

Revue de synthèse : IV $\mathrm{S} . \mathrm{N}^{\text {os }}$ 3-4, juillet-décembre 1994. 
logia" ${ }^{2}$. Aristotelian textbooks of philosophy placed the study of the soul, including the rational soul and intellect, under the rubric of physics or natural science, together with the study of basic physical principles, body in general, and the heavens ${ }^{3}$. Although the "new philosophers" of the seventeenth century uniformly rejected (in their various ways) the Aristotelian theory of the soul as the substantial form of the body, they did not always deviate from the Aristotelian conception of physics as the science of nature in general, including the human mind. As the eighteenth century opened, then, it was an academic commonplace that the science of the mind or soul belongs to physics or the science of nature.

Eighteenth-century writers made many proposals for changing or newly founding the study of the human mind. A few contended that the study of the mind could not be made sufficiently rigorous to rank as a science ${ }^{4}$. The most famous was Kant, though he nonetheless put empirical psychology under the rubric of physics (physiologia) and remained committed to the applicability of the law of cause to all psychological phenomena ${ }^{5}$. But a large number of authors, British, Swiss, and especially German, proposed and sought to practice an "experimental" - that is, an "empirical" and "observational" - "science of the mind", a scientific psychology. This activity was surveyed by F. A. Carus in his Geschichte der Psychologie of 1808 , in which he discussed more than 125 eighteenth-century authors, mostly German, but also British, French, Swiss, Italian, Spanish, and Swedish, who wrote psychological works of some type, the majority placing psychology under the rubric of natural science ${ }^{6}$.

2. Otto CASMann, Psychologia anthropologica, sive animae humanae doctrina, Hannover, apud G. Antonium, impensis P. Fischeri, 1594; Rudolph GocLenIus, Psychologia : hoc est, de hominis perfectione, animo, Marburgh, ex officina Egenolphi, 1590; Fortunio LiCETI, Psychologia anthropine, sive de ortu animae humanae. Frankfurt-am-Main, ex officina Joannis Saurii, 1606. On psychology in the sixteenth and seventeenth centuries, see Paul MENGAL, "Naissances de la psychologie : la nature et l'esprit", Revue de synthèse, this issue, p. 355-373.

3. Pierre Barbay, In universam Aristotelis philosophiam introductio, 6th ed., Paris, apud Ludovicum Josse, 1700, "Compendii physici", pt. 2, tr. 2, a. 3; Franco BuRGersDuJck, Collegium physicum, disputationibus XXXII, Oxford, typis W. Hall, impensis Joseph Godwin, 1664, disp. 20-31; Eustace of St. Paul, Summa philosophiae quadripartita, Köln, typis Philippi Alberti, 1638, pt. 3, "Physica", tr. 3, disp. 3-4, p. 228-308. The Aristotelian concept of soul (psyche, anima) extends to vegetative and nutritive, as well as sensory and intellectual, powers and capacities.

4. Julius B. von RoHR, Unterricht von der Kunst, der menschen Gemüther zu erforschen, Leipzig, Verlegts Johann Christian Martini, 1721; Charles de SECONDAT, baron de MontesQUIEU, De l'esprit des loix, Geneva, Barrillot, 1748, bk. I, chap. 1, p. 3-5.

5. Gary HatFiELD, "Empirical, Rational, and Transcendental Psychology : Psychology as Science and as Philosophy", in Cambridge Companion to Kant, ed. Paul GuYER, Cambridge, Cambridge University Press, 1992, p. 200-227.

6. Friedrich A. CARUS, Geschichte der Psychologie, Leipzig, I.A. Barth und P.G. Kummer, 1808, p. 522-760. A century later, Max Dessorr stressed the prominence of psychology in the eighteenth century, Geschichte der neueren deutschen Psychologie, 2nd ed., Berlin, Carl Duncker, 1897-1902, p. 358. 
This description of psychology in the seventeenth and eighteenth centuries contradicts the received historiography. Recent general histories of psychology agree that natural-scientific psychology arose only in the second half of the nineteenth century ${ }^{7}$. Some historians, taking their cue from this historiography, have sought to explain why psychology did not arise in the previous centuries ${ }^{8}$. Only a few recent studies treat the earlier calls for a "natural scientific" psychology as anything but empty thetoric". And I have found no recent author who acknowledges that psychology was considered a natural science as the eighteenth century opened and that it had been so considered in Europe for several centuries.

The contradiction between my description of eighteenth-century psychology and the traditional historiography arises partly from differing understandings of the concepts psychology and natural science. In the past halfcentury there has been a decided tendency to equate "natural scientific psychology" with "quantitative, experimental psychology", and to contrast the "scientific" character of this psychology with the "metaphysical" character of its earlier namesake. This tendency is not surprising : the growth of psychology as a scientific discipline has been built on its claim to apply quantitative experimental rigor to subject-matters about which philosophers and metaphysicians only talked and speculated. If one equates modern science with quantitative science, then there could be no scientific psychology prior to the widespread adoption of quantitative experimental techniques in the period after 1850. If one confines modern science to its non-metaphysical moments, then metaphysically inclined theorists and experimentalists must be excluded, or else only a "sanitized" version of their work allowed in. These two constraints on legitimacy conjointly explain why the great body of eighteenth-century literature claiming to found a natural scientific psychology has been largely ignored by historians of psychology.

The equation of natural science with anti-metaphysical, quantitative experimentation is problematic on two counts. As an approach to history, it

7. Edwin G. BoRING, History of Experimental Psychology, 2nd ed., New York, AppletonCentury-Crofts, 1950; Duane P. SchulTz and Sydney Ellen Schustz, History of Modern Psychology, San Diego, Harcourt Brace Jovanovich, 1987; Richard LowrY, Evolution of Psychological Theory, 2nd ed., New York, Aldine Publ. Co., 1982; Daniel N. Robinson, Intellectual History of Psychology, rev, ed., New York, Macmillan Publ. Co., 1981 .

8. E.g., Graham Richards, "The Absence of Psychology in the Eighteenth Century : A Linguistic Perspective", Studies in History and Philosophy of Science, 23, 1992, p. 195-211.

9. Christopher Fox, "Defining Eighteenth-Century Psychology : Some Problems and Perspectives", in Psychology and Literature in the Eighteenth Century, ed. Christopher Fox, New York, AMS Press, 1987, p. 1-22; Rolf JESCHONNEK, introduction to the reprint edition of Carus's Geschichte, Berlin/New York, Springer Verlag, 1990, p. 17-37; Eckart ScreERER, "Psychologie", in Historisches Wörterbuch der Philosophie, ed. Joachim RitTer, Basel, Schwabe, 1971-, t. VII, col. 1599-1653; Fernando VDaL, "Psychology in the 18th Century", History of the Human Sciences, 6, 1993, p. 89-119. Now joined by P. MEvGAL, art. cit. supra, n. 2 . 
partakes of the worst failings of "presentist" and "Whig" history : it ignores the self-understanding of earlier figures who considered themselves practitioners of natural science, and it redescribes their cognitive activity and intellectual products from the standpoint of the presently ruling party, in this case, the community of experimental psychologists and their historians and apologists. Philosophically, it makes a crude positivist assumption that all progress in science is progress in the quantitative description of natural phenomena. This philosophical position should be resisted : not all natural scientific achievements ate fundamentally quantitative, including achievements in two sciences that are closely related to psychology, physiology and biology (consider the discovery of neurons, or the early development of the theory of evolution). Moreover, in the early history of physics an important role was played by conceptual innovation as opposed to quantitative prediction or modeling, as exemplified in Descartes' contribution to the development of the concept of a unified celestial and terrestrial physics, (metaphysically) grounded on a small set of basic concepts, laws, and patterns of explanation ${ }^{10}$. One should not rule out the possibility that in psychology, too, important conceptual work preceded quantitative experimentation.

\section{A. CONTEXTUALIST APPROACH TO THE ORIGIN OF "NATURAL SCIENTIFIC" PSYCHOLOGY}

During the eighteenth century, as in the seventeenth, "psychology" was the science of mind or soul, or of mental phenomena; as such, it was known under many names, deriving from "psyche", "anima", "soul", "mind", and their cognates ". Mind and soul were often, but not always, equated. The mind or soul was considered by many to be a natural being, a thing in nature ${ }^{12}$. "Science" was applied to any systematic body of thought,

10. I. B. Cohen, Newtonian Revolution, Cambridge, Cambridge University Press, 1980, p. $182-189$; G. HATFIELD, "Metaphysics and the New Science", in Reappraisals of the Scientific Revolution, ed. David LindBerg and Robert WestMan, Cambridge, Cambridge University Press, 1990, p. 93-166.

11. Many historical investigations, including Vidal's helpful "Psychology in the Encyclopedias", have focused on the origin of the word "psychology", as opposed to the origin of psychology as a discipline. But the aetiology of concepts must be distinguished from the (allied) histories of word usage. The science of the mind was known under many titles in the eighteenth century, including "the science of the mind", "the theory of mind", "psychology", "psychologie", "Psychologie", and "Seelenlehre". Related disciplines included "anthropology", or the "science of Man", differing instances of which paid greater or lesser attention to human mental life, and "pneumatics", "pneumatology", or "Geisterlehre", which considered spirits (immaterial beings).

12. Even a Cartesian could include the study of the soul under the rubric of "physics" : Antoine LE GRAND, Institutio philosophiae secundum principia de Renati Descartes, London, J. Martyn, 1678, praecognoscenda, a. 7, 15, 16. 
and need not have connoted an empirical basis. "Natural science" was equated with "physics", in the etymological sense of that term; it was the science of nature ${ }^{13}$. In the seventeenth and throughout much of the eighteenth centuries this science included the whole of nature, comprising a subject-matter that we would now range under the headings of physics, physical astronomy, chemistry, biology, physiology, and psychology.

Given these understandings of the terms and the areas of study they denote, psychology was considered by a great many eighteenth century authors to be a science. This was so whether psychology was treated as a science of mental phenomena or of mental substance. Many considered it to be a natural science based on experience, including those who considered themselves to be studying an immaterial substance. A minority of the latter group followed Christian Wolff in placing psychology under the rubric of metaphysics rather than physics. This fact, however, requires careful interpretation, for Wolff also placed cosmology (general physics, including planetary astronomy and the laws of motion) under metaphysics, and he allowed that metaphysical principles could and should be established empirically ${ }^{14}$. Thus, if one takes eighteenth-century conceptions of psychology seriously across the board, as I intend to do, one is committed to allowing immaterial substances as a (putative) object of empirical study.

This last observation, even cushioned as it is by the surrounding contextualist historical methodology, is likely to shock modern sensibilities. This shock is another manifestation of our use of present standards (and mythologies) to judge past materials. Immaterial substances are not in the list of likely theoretical posits in current psychology and physiology. One way of interpreting this fact is to think that such posits were part of a religious world view that was overcome with the Enlightenment rejection of superstition and authority. "Reason", so the story often goes, has shown us that dualism and other mind-positing ontologies are empty or incoherent.

This way of understanding the Enlightenment and the dictates of reason is itself unreflective and simplistic. It is true that some Enlightenment "philosophes" are justly portrayed as rejecting God and the soul on rational grounds, in opposition to tradition and authority. But one should not leap to

13. For eighteenth-century definitions (explicit and implicit) of the terms marked by quotation in this paragraph, see Ephraim Chambers, Cyclopaedia, or An Universal Dictionary of Arts and Sciences, 2nd ed., London, D. Midwinter, 1738; Immanuel KANT, Kritik der reinen Vernunft, Riga, Hartknoch, 1781/1787, "Methodenlehre", pt. 3 (Kant uses the Latin term "physiologia" for the science of nature).

14. Christian WoLfF, Philosophia rationalis sive logica, 3rd ed., Frankfurt-am-Main/Leipzig, prostat in Officina Libraria Rengeriana, 1740 : philosophical cognition requires "historical" cognition of facts $(\$ 50)$ and metaphysics is a species of philosophy $(\$ 79)$. Further, psychology is a part of metaphysics, and it requires cognition of facts from experience in both its empirical and rational branches : Psychologia empirica, new ed., Frankfurt-am-Main/Leipzig, prostat in Officina Libraria Rengeriana, 1738, § 1-4. 
the converse conclusion, for it is not true that all those who posited immaterial substances were blind followers of tradition and authority. Indeed, a chief characteristic of many who were metaphysical realists about the soul was their appeal to reason or intellect in establishing their ontologies : Descartes is the most notorious example. In any event, if one believes that immaterial entities exist and that some of them inhabit human bodies, it makes good sense to seek to determine the powers and capacities of such substances empirically, by studying the manifestation of the mind in the behavior of others and in one's own experience of mental phenomena. From this point of view, taking an empirical approach to immaterial substances is an extremely rational undertaking. How else is one to determine their powers ${ }^{15}$ ?

When viewed contextually, psychology as a natural science was not invented in the nineteenth or even the eighteenth century; but during the eighteenth century it was altered from its seventeenth-century form. As the eighteenth century opened the science of the mind included several dimensions : charting the "faculties" - the capacities and powers - of mind was foremost, but there also were metaphysical questions about the ontology of the mind and its faculties, and about their relation to body and to specific bodily organs, especially the brain. As the century proceeded, the study of the mind was displaced from its subdisciplinary status in the Aristotelian curriculum and pursued along several lines, including explicitly Christian apologetical approaches to the soul, and the diametrically opposed materialism of the philosophes and their Scottish counterparts - including Diderot, d'Holbach, Helvetius, Priestley, and Bentham - which has received the most attention in histories of Enlightenment psychology, as part of the usual story of the Enlightenment banishment of spirits and the alliance of materialism with progressive thought and politics ${ }^{16}$. Between these two extremes lay the largest and richest body of literature, that of the manifold programs for adopting an empirical approach to mind and its relation to body. Such programs were pursued in various disciplinary matrices, in-

15. Aristotelians also quite reasonably took an empirical attitude toward the powers of the soul, considered as an animating principle. A similar point might be made about the study of an immaterial supreme being; hence, the extensive practice of "natural theology" during the eighteenth century. There is a tension between characterizations of the Enlightenment as "The Age of Reason" and as anti-clerical and secular. "Enlightenment" has two distinct connotations, one based on cognitive attitude or "method", another on content and conclusion. According to the first, it means "thinking for one's self", to the second, it includes rejection of the immaterial beings posited itl many religions. Tension arises because supreme rationalists such as Descartes and Leibniz "thought for themselves" and claimed to establish the existence of God and the soul through reason. This apparent conflict should, I think, serve to sensitize us to the changing content assigned to reason or "the rational" in the modern period.

16. Simon Schaffer, "States of Mind : Enlightenment and Natural Philosophy", in Languages of Psyche, ed. George S. Rousseau, Berkeley/Los Angeles/London, Universtity of California Press, 1990, p. 233-290. 
cluding the newly founded and widely influential Wolffian matrix in Germany; the "science of the mind" allied with Scottish moral philosophy; the proposal of a "natural history" of mind (and of Man) by the prominent Swiss naturalist Charles Bonnet; and treatments of mind in the established contexts of medical physiology and the theory of vision. The faculty-based approach dominated the most prevalent form of dualistic psychology, the avowedly non-metaphysical Erfahrungsseelenlehre. An alternative to faculty psychology began to be widely discussed in the middle of the eighteenth century : the associationist theory of mind propounded by Hartley, Hume, and others, which attempted to explain all or most phenomena of mind by appeal to a few laws of association (usually three).

A detailed road map through this diverse material cannot be attempted here; I aim instead to sketch the three most visible empirical approaches to the mind and to determine their self-ascribed disciplinary locations. The three are: Wolffian psychology, Scottish sciences of Man, and German Erfahrungsseelenlehre.

THE WOLFFIAN DISCIPLINARY CONTEXT FOR PSYCHOLOGY

Christian Wolff created the paired disciplines of empirical and rational psychology, which he ordered coordinately with ontology, cosmology, and natural theology under metaphysics ${ }^{17}$. His efforts have been the butt of many jokes in the history of psychology, most notably of Wundt's famous jest that Wolff's rational psychology "contains about as much experience as the empirical, and the empirical about as much metaphysics as the rational $^{\text {" } 18}$. In the standard historiography, Wolff is part of the metaphysical past of psychology's prehistory. His work is paradigmatic of the allegedly regressive tendencies of pre-scientific, speculative or metaphysical psycho$\operatorname{logy}:$ it is organized around the study of mental faculties, and it adopts a realistic attitude toward the soul considered as an immaterial substance.

In the context of the eighteenth century, however, Wolffian empirical psychology was a progressive research program. It was novel in both content and methodology. Its major methodological innovation was the explicit enjoinder to adopt an empiricist attitude toward mental faculties and phenomena: they were to be studied by attending to their operations,

17. See Philosophia rationalis, op. cit. supra n. 14, \&79; see also Alexander Gottlieb BaumGarten, Metaphysica, 7th ed., Halle, C. H. Hemmetede, 1779.

18. Wilhelm WundT, Grundzüge der physiologischen Psychologie, 3rded., Leipzig, W. Engelmann, 1887, p. 7. 
while holding metaphysical speculation in abeyance. The facts thus attained are then examined within rational psychology, in order to determine appropriate explanatory (we would say "theoretical") principles ${ }^{19}$. Within this scheme, the description of mental faculties is not intended to be explanatory (as was the dormitive virtue portrayed in Molière's joke), but descriptive of a unified capacity of the mind. Such descriptions, being classificatory, are not atheoretical; but because they were not intended to be explanatory, they are not subject to Molière's joke (any more than are current psychological investigations of cognitive and perceptual capacities) ${ }^{20}$. Within his empiricist program, Wolff claimed that psychological states, and particularly those pertaining to pleasure and pain, are subject to quantitative measurement and mathematical laws, although he did not himself formulate a calculus of pleasure. He also suggested that the goodness of one's memory can be estimated by the temporal latency of response to a memory demand, from the number of tries it takes to retrieve from memory, and from the number of acts it takes to fix an item in memory. He suggested a corresponding quantitative estimate for the size of memory ${ }^{21}$.

In content, the Wolffian psychology was noteworthy for its analysis and discussion of the faculties of imagination, attention, and reflection. Wolff distinguished imagination proper, which simply reproduces sensory materials, from the faculty of "feigning" or producing new representations (facultas fingendi). He described the "law of imagination", a law of association through simultaneity. And he discussed attention and its subspecies, "reflection" (or attention to the content of one's perceptions), including impediments to their exercise 22 .

The Wolffian system was widely influential in Germany, where it displaced the fading Aristotelian and Cartesian school philosophies. Numerous textbooks of Wolffian philosophy came off the presses, and they were used even by authors who no longer subscribed to their precepts, including

19. C. Wolf, Psychologia empirica, op. cit. supra n. 14, \& 1-4; Psychologia rationalis, new ed., Frankfurt-am-Main/Leipzig, prostat in Officina Libraria Rengeriara, 1740. \& 1-3. For English translation and discussion, see Robert J. Richards, "Christian Wolff's Prolegomena to Empirical and Rational Psychology : Translation and Commentary", Proceedings of the American Philosophical Society, 124, 1980, p. 227-239.

20. Jerry Fonor jocularly defends faculty psychology in his Modularity of Mind, Cambridge, Mass. The MIT Press, 1983. More seriously, the organization of psychology textbooks has long bom the stamp of the traditional division of faculties, as psychologists have studied the functionally characterized faculties of cognition, including perception, learning, and memory, and more specific capacities, such as visual perception, and within vision, color, shape, and motion perception.

21. C. Wouff, Psychologia empirica, op. cit. supra n. 14, \& 190-194.

22. Ibid., pt. 1, sec. 2, chap. 3-4; sec. 3, chap. 1; Psychologia rationalis, op. cit. supra n. 19 , pt. 1, sec. 1 , chap. $3-4$. 
Immanuel Kant ${ }^{23}$. The system was also rendered into French by the Berlin Wolffian, Jean Deschamps ${ }^{24}$.

SCOTTISH SCIENCES OF MAN AND MIND

In the Scottish Universities of the first half of the eighteenth century the mind was studied in three areas of the revised Aristotelian curriculum : logic, metaphysics, and moral philosophy (which discussed appetite). By mid century, a peculiarly Scottish phenomenon had occurred : within the university arts curriculum, the study of the mind in general became the special preserve of moral philosophy (as might be expected of the "moral sense" school). Thomas Reid, professor of moral philosophy at Glasgow, transformed moral philosophy into the examination of the "powers" of the mind. At Edinburgh, when Adam Ferguson became professor of moral philosophy and pneumatics in 1764 , he answered to his title by making the "theory of mind" a proper part of his basic textbook, the Institutes of Moral Philosophy ${ }^{25}$.

The fact that the study of the mind fell largely under moral philosophy in the Scottish arts curriculum does not imply that the mind was considered to be distinct from nature or from natural scientific methods of study and modes of explanation. Indeed, it was characteristic of Scottish philosophers to adopt a naturalistic attitude toward the mind and its powers. Hume signaled his naturalistic intentions in the subtitle to his Treatise of Human Nature: Being an Attempt to Introduce the Experimental Method of Reasoning into Moral Subjects; in the introduction, he explicitly compared his methods and modes of explanation to those of Newton ${ }^{26}$. Ferguson, in his telegraphic Institutes of Moral Philosophy, formulated natural laws of both matter and mind, distinguishing the latter from properly moral laws. He defined moral philosophy as "the knowledge of what ought to be", and declared that "pneumatics, or the physical history of mind, is the foundation of moral philosophy". The term "physical" is not used here to

23. Among the many Wolffian textbooks, Kant is known to have taught from A. G. BAuMGARTEN's Metaphysica, op. cit. supra n. 17.

24. Jean Deschamps, Cours abrégé de la philosophie wolffienne, Leipzig/Amsterdam, Arkstee \& Merkus, 1743-1747.

25. Thomas Rem, On the Active Powers of Man, Edinburgh, J. Bell, 1788. Adam FERGUson, Institutes of Moral Philosophy, 2nd ed., Edinburgh, A. Kincaid \& W. Creech and J. Bell, London, S. Crowder, 1773, pt. 2.

26. London, 1739-1740. Besides Hume, Hartley, Reid, and Ferguson adopted "Newtonian" approaches to mind: Gladys Bryson, Man and Society: The Scottish Inquiry of the Eighteenth Century, Princeton, Princeton University Press, 1945, p. 18-21, 138-139, 145. 
announce a physicalist or reductionist theory of mind ; rather, it is used to mean "any general expression of a natural operation, as exemplified in a number of cases". The natural laws of mind were named "physical" by Ferguson in order to contrast them with the moral laws that serve to guide conduct ${ }^{27}$. Examples of the former "laws" include the facts that we are conscious of our "existence, operation, and will", and that perception takes place via media that do not resemble the object of perception ${ }^{28}$.

\section{ERFAHRUNGSSEELENLEHRE}

While in the Scottish context investigators sought to make the mind an object of empirical investigation and to discover its "physical laws" as a prolegomena to morals, in Germany the science of the soul (or mind) was treated as an autonomous discipline - or as a subdiscipline of the science of Man - within the theoretical (as opposed to moral) sciences. The framers of "Seelenlehre", "Erfahrungsseelenlehre", and "empirische Psychologie" aspired to such an empirical approach to the soul or mind. Early instances are found in the work of J.F. Abel and C. C. E. Schmid. Abel and Schmid placed empirical psychology within natural science proper, distinct from metaphysics; they considered psychology to be the branch of anthropology or Menschenlehre that searches for the general laws of the mind and its relation to the body ${ }^{29}$.

Abel's book exhibits a typical psychological textbook organization, with roots in the de anima tradition. After brief preliminary methodological remarks, it considers first the nature of the mind, its basic powers and organs, and especially its relation to the brain, and then it surveys in systematic fashion the chief faculties of mind : sense, imagination, attention, thought, feeling, and bodily motion. Throughout, Abel attempts to show how all of the various powers and capacities of the mind can be reduced to one basic power, the power of representation, and how the materials on which the power of representation operates must all derive from sensory ideas aroused through stimulation of the sense organs. As had become common in the eighteenth century, he showed an interest in quantitative measures where these were available; indeed, he gave quantitative values

27. A. Ferguson, op. cit. supra n. 25, Introd., sec. 7 ; sec. 3.

28. Ibid., pt. 2, chap. 2, sec. 1.

29. Jacob Friedrich ABEL (Professor of Psychology and Morals at the Karlsschule), Einleitung in die Seelenlehre, Stuttgart, Johann Benedikt Mezler, 1786, Einleitung; Carl Christian Eberhard ScHm[D (Professor of Philosophy, Jena), Empirische Psychologie, 2nd ed., Jena, Cröker, 1796, p. 8, 11-12. 
for the "briefest still perceivable duration" of an impression on the sense organs. But the primary theoretical interest of the work was the discovery of "laws" governing the various faculties, including laws of association and attention ${ }^{30}$. The laws of attention assumed an all or none "conquest" (siegen) of attention by one or another representation. Originally, the currently liveliest or most pleasant representation wins out, but through experience it may happen that a less lively or pleasant representation that has in the past been followed by more pleasant representations will win out; the attentional faculty then comes to be guided by means-ends considerations in choosing which representations to enhance through its own power.

Many of the topics in Abel's textbook, such as the perception of size, shape, location, and distance, and attentional "conquest", can be found in nineteenth- and in early and late twentieth-century textbooks. But one set of questions would no longer be found after ca 1930 : those pertaining to the existence and nature of the soul. The framers of Seelenlehre typically argued that the soul is a separate substance from the body, and they did so on philosophical as opposed to religious grounds. Abel repeated the widely used argument that the unity of consciousness requires a unified substance as its vehicle; but body is essentially conglomerate; hence, the simple substance that is mind must be distinct from body. He took this argument to be an exemple of empirical investigation. He divorced his investigation from "metaphysical" considerations that transcend experience, e.g., about mind-body interaction. Historians of psychology typically lump together talk of a separate thinking substance and of mind-body interaction as "metaphysics". Here, an eighteenth-century author asserts a different dividing point. He holds that empirical considerations can be brought to bear on the existence and nature of the soul. He does not mean that one can simply introspect and discover the simple substance of the soul. An argument is required : a theoretical structure must be fit to the "data" of inner sense. But he considered these questions on the soul to be empirically tractable, by contrast with the problem of mind-body interaction, which admits of multiple hypotheses that "save" the phenomena without differing empirically. He excluded the latter, empirically-undecidable problem from his Seelenlehre ${ }^{31}$.

Schmid drew the boundaries of the empirical more narrowly than had Abel. He followed Kant in removing questions pertaining to the substantiality and simplicity of the soul from the domain of empirical investigation and relegating them to "dogmatic" metaphysics - for which he reserved

30. J. F. ABEL, op. cit. supra n. 29 , § 148-163, 194-206.

31. Ibid, \& 4-20. 
the names "transcendental" or "pure" psychology, or "pneumatology", thereby deviating from Kant's terminology. Included here were questions pertaining to the independence, simplicity, personhood, spirituality, immutability, and immortality of the soul, as well as those pertaining to its real causal relation to body. He used the terms "empirical" and "rational" psychology as Wolff had, to denote disciplines that are based directly on experience (or are a posteriori) and those that are based on the analysis of concepts that themselves are drawn from experience (and hence are "comparatively a priori") ${ }^{32}$. The rational part of psychology constructs explanations for the empirical generalizations and other data collected in the empirical part.

Having relegated the problem of the substantial nature of the mind to the domain of dogmatic metaphysics, Schmid adopted a position of "empirical dualism" 33 . Empirical dualism distinguishes soul and body on the grounds that the properties and phenomena revealed through outer and inner sense cannot be united under a single set of concepts. Experience shows that the phenomena of each are lawfully related. Empirical psychology charts lawful relations within the domain of soul, spirit, or mind, and between that domain and bodily processes. Schmid's work is particularly impressive for its detailed analytical treatment of psychological concepts informed by a thorough acquaintance with the psychological, anthropological, and medical literatures.

EMPIRICALLY AND THEORETICALLY PROGRESSIVE RESEARCH PROGRAMS

According to the usual sociological measure of progressiveness, psychology was a progressive discipline during the eighteenth century : academic appointments in psychology were made, courses were taught, the number of textbooks published per decade increased, and, near the end of the century, journals were founded (even if they failed within a decade) ${ }^{34}$. But I would like to make a stronger claim for the progressiveness of various eighteenth-century research programs that took a natural scientific attitude toward the mind or mental phenomena. I propose as a working historical thesis that eighteenth-century work made a threefold contribution to the psychology of the nineteenth century. First, eighteenth-century faculty psychology yielded a conceptual framework that was more fine-grained than

32. C. C. E. Schmid, op. cit. supra n. 29, p. 18-26.

33. Ibid, p. 189-190.

34. These claims are supported by F. A. CARUs's Geschichte, op. cit. supra n. 6, and C. C. E. SchmD's overview of the literature, op. cit. supra n. 29, p. 142-156. 
that of earlier centuries, and that benefited nineteenth-century investigations. Second, eighteenth-century association psychology provided the theoretical framework that dominated much nineteenth-century psychology, the associationist framework. Third, eighteenth-century experimental work, especially in vision, provided a tradition of experimental practice that, although not often counted as part of "psychology" so called during the eighteenth century, was incorporated into the "new" experimental discipline of psychology during the nineteenth century. Further development of the long-standing tradition of experimental work on vision provided the primary foundation for the claims to found a new, experimental psychology.

A survey of that subset of popular late nineteenth- and early twentiethcentury psychology textbooks that treat psychology as a natural science would reveal that the structure of these books has much in common with scholastic textbooks of the seventeenth century : the external senses, their organs and associated nervous processes, are treated first; the "internal senses" (usually not so called) are treated further on, including memory and imagination; higher cognitive faculties, including reasoning, further on; bodily motion, somewhere along the way; and appetite and will, near the end ${ }^{35}$. We can discover the specifically eighteenth-century contribution by finding those new chapters in these textbooks that have origins in that century. The new chapters include those on attention, conception or abstraction, and association. Attention was brought into psychology by the faculty tradition, particularly by Wolff and his followers, and was further addressed in Erfahrungsseelenlehre, which proposed empirical constraints on the scope and direction of attention ${ }^{36}$. The chapters on discrimination and on conception or abstraction, though rooted in ancient Greek philosophy, were introduced into eighteenth-century psychology books by those developing the faculty approach ${ }^{37}$. The added chapter on association was due largely to attempts by authors such as Hume and Hartley to make the laws of association the fundamental explanatory principles of mind ${ }^{38}$.

35. W. JAMEs, op. cit. supra n. 1; Edward B. TrTCHENER, Outline of Psychology, new ed., New York/London. Macmillan, 1901 ; Hermann Ebeinghaus, Abriss der Psychologie, 4th ed., Berlin/Leipzig, Walter de Gruyter, 1912; Edward L. ThorNDIKE, Elements of Psychology, 2nd ed., New York, A. G. Seiler, 1915; W. WuNDT, Grundriss der Psychologie, 13th ed., Leipzig. A. Kröner, 1918; H. A. CARR, op. cit. supra n. 1.

36. C. Wolf, Psychologia empirica, op, cit. supra n. 14, pt. 1, sec. 3, chap. 1. J. F. ABEL, op. cit. supra n. 29, \$194-268. Nicolas MaLEBRANCHE previously had placed attention at the center of his discussion of method, Recherche de la vérité, bk. 6, pt. 2, in his Euves, ed. André Robinet, Paris, Vrin, 1958-1970, t. II.

37. C. Wolff, Psychologia empirica, op. cit. supra n. 14, pt. 1, sec. 3, chap. 1; Psychologia rationalis, op. cit. supra n. 14, pt. 1, sec. 1, chap. 4; J.F. ABEl, op. cit. supra n. 29 , $\S 392-436$.

38. D. Hume, Treatise, op. cit. supra n. 26, bk. 1, pt. 1, sec. 4; David HartLeY, Observations on Man, London, S. Richardson, 1749, pt. 1, chap. 1, prop. 10-14, and passim. C. WolfF 
Thus far my analysis of the "progressive" tenor of eighteenth-century psychology has been restricted to changes in psychological textbooks, which may or may not have claimed novel conceptual and theoretical results, and which only sometimes claimed to present original observations. One might concede that this older tradition contributed conceptual materials to the textbooks of the new psychology of the nineteenth century, without accepting that the eighteenth century contributed to the rise of experimental psychology. In fact, the strongest eighteenth-century contribution to the rise of quantitative experimentation in psychology came from the mixed-mathematical science of optics.

Optics was a "mathematical" science in virtue of its use of geometrical constructions, especially in the tracing of "visual rays". As regards vision proper, these rays were used in the analysis of the perception of size, shape, distance, and motion. Mathematical (geometrical) regularities, such as that among visual angle, apparent distance, and perceived size, were typically expressed as proportions. There were few numerical values in optics (indices of refraction being one). In the seventeenth century Descartes gave estimates of the range within which accommodation and convergence could provide accurate information for the perception of distance, though he did not say how he had arrived at the values. Berkeley, who introduced a conceptual revolution into the theory of vision with his doctrine of suggestion, did not cite quantitative observational evidence ${ }^{39}$. The eighteenth century was replete with novel observations of sensory phenomena, including after-images and color blindness, that were not quantitative, but were nonetheless important for that ${ }^{40}$.

Nonetheless, there were quantitative studies of visual perception in the eighteenth century, among which I give three examples. Patrick D'Arcy measured the persistence of visual impressions by devising an apparatus for presenting a luminous object (a live coal) to an observer with a circular motion whose diameter, velocity, and distance from the observer could be varied. By observing how rapidly the coal must turn in order to result in the perception of a closed circle with constantly fixed gaze, he concluded that

described the phenomena of association and their law, Psychologia empirica, op. cit. supra n. 14, $\$ 104,117$; his follower A. BAumoarten named "associatio idearum" the "lex imaginationis", op. cit. supra n. $17, \S 561$.

39. On Descartes and Berkeley, see Gary Hatrield and William Efsteis, "The Sensory Core and the Medieval Foundations of Early Modern Perceptual Theory", Isis, 70, 1979, p. 363-384.

40. On after-images, see Georges Louis Leclerc, comte de Burfow, "Dissertation sur les couleurs accidentelles", Mém. Acad. Sciences, 1743, Paris, 1746, p. 147-158. John Dalton, "Extraordinary Facts Relating to the Vision of Colours: with Observations", Memoirs and Proceedings of the Literary and Philosophical Society of Manchester, 5, 1798, p. 28-45. 
the impression lasts for " 8 tierces" 41 . Pierre Bouguer examined the question of how lines must be rendered in perspective to yield an appearance of being parallel, which was a problem addressed by several mathematical theorists. He introduced into the problem the notion of the apparent (as opposed to real) inclination of the ground plane, and measured the latter ${ }^{42}$. Robert Smith undertook a thorough study of the moon illusion, which he explained in accordance with the hypothesis that for a given visual angle, perceived size varies with apparent distance. He contended that the moon appears larger at the horizon because it seems further away than when it is overhead. In support of this hypothesis, he undertook to measure the perceived curvature of the vault of the heavens, which informal observation suggested is flattened. He obtained numerical values by comparing the known position of the stars with the apparent bisections by visible stars of the angle between the horizon and straight overhead ${ }^{43}$.

The practice of seeking precise measurements in testing theories of perception became more common in the nineteenth century, and was particularly highly developed in German sensory physiology and psychology. Wundt and Helmholtz drew upon earlier work when they brought sensory psychology into a position of scientific prominence, and not solely with respect to experiment; equally or more importantly, their theoretical conceptions were inherited from the highly developed theories of spatial perception that arose in the eighteenth and early nineteenth centuries ${ }^{44}$.

\section{CONCLUSIONS}

Psychology or the science of the mind was conceived as a natural science in the seventeenth, eighteenth, and nineteenth centuries all three. The notions of psychology and natural science underwent significant change along the way. At first "psychology" was the science of the Aristotelian soul, and covered vegetative as well as sensory and intellectual

41. Patrick D’Arcy, "Mémoire sur la durée de la sensation de la vue", Mém. Acad. Sciences, 1765, Paris, 1768, p. 439-451.

42. Pierre Bouguer, "Recherches sur la grandeur apparente des objets", Mém. Acad. Sciences, 1755, Paris, 1761, p. 99-112.

43. Robert SмrTh, Compleat System of Opticks, Cambridge, printed for the author and sold by C. Crownfield, 1738, t. I, p. 63-66. All three examples, along with others, are reported in Joseph Priestley, History and Present State of Discoveries Relating to Vision, Light, and Colours, London, J. Johnson, 1772.

44. G. HATfield, The Natural and the Normative: Theories of Spatial Perception from Kant to Helmholtz, Cambridge, Mass., The MIT Press, 1990, chap. 2, 4, 5. 
powers; study of the latter, "cognitive" powers was a (dominating) subdiscipline in Aristotelian psychology. Wolffians made psychology a part of metaphysics, coordinate with cosmology. Scots placed psychology within moral philosophy, but distinguished its "physical" laws from properiy moral laws (for guiding conduct). Several Germans sought to establish an autonomous empirical psychology. Meanwhile, British and French visual theorists developed sophisticated theories of spatial perception and mathematically precise theories of size and distance perception; they created instruments to test these theories, and to measure other visual phenomena, such as the duration of visual impressions. Nearly all of these investigators were dualists of one sort or another. From early to late, the trend was to bracket metaphysical questions in favor of the search for empirical regularities and empirically-based systems of classification. These empirical studies were directed at mental phenomena considered as distinct from material phenomena.

This sketch of the early history of psychology challenges not only the usual historiography, but also the usual conception of Enlightenment progress. In the standard narrative, the heroes of the Enlightenment are materialists. If psychology is to be made a science, the story goes, mind must be equated with matter and thereby rendered subject to empirical investigation ${ }^{45}$. The problem is that no one bothered to tell the early practitioners of natural scientific psychology that they had to be materialists in order to be natural scientific psychologists. In point of fact, of all the major eighteenthcentury authors who made contributions to the development of psychology, only Erasmus Darwin allowed that mind might be material; nineteenthcentury founders of psychology, including Wundt, Helmholtz, Lotze, Ebbinghaus, James, Munsterburg, and Binet, banished the very question from scientific psychology ${ }^{46}$. These authors conceived psychology as natural scientific without seeing the need to adopt the metaphysical position of materialism. In so doing, they would seem to be proceeding quite rationally, by studying what can be studied on its own terms and avoiding an unnecessary commitment to the unsupported claim that mental phenomena can be reduced to material processes. The old equation of Enlightenment Reason with materialism turns out to have been so much prejudice. It would be interesting to discover the historical conditions in which this version of history became entrenched. In the meantime, there is much work to

45. S. SCHAFFER makes this position explicit, art. cit. supra n. 16, p. $240,263$.

46. Erasmus DarwIN, Zoonomia, or the Laws of Organic Life, London, J. Johnson, 1794, t. I, p. 108-109. On anti- and non-materialistic stances in eighteenth and nineteenth-century psychology (including Wundt, Helmholtz, and Lotze), see op. cit. supra n. 44, chap. 6-7. W. JaMes, op. cit. supra n. 1, p. 6-7. Hugo Munstergerg, Psychology : General and Applied, New York/London, D. Appleton \& Co., 1914, p. 39-42. Alfred BiNET, Introduction à la psychologie expérimentale, Paris, F. Alcan, 1894, p. 146. 
be done investigating the history of psychology considered as the science of mental phenomena, a history in which faculty psychology is no joke, and in which materialism is virtually nowhere to be found.

Gary HatField, University of Pennsylvania, Department of Philosophy,

Suite 460, 3440 Market Street, Philadelphia, PA, 19104-3325

U.S.A.

(April 1994). 